\title{
PRAKTIK MACHIAVELLIAN BERBASIS GENDER MAHASISWA AKUNTANSI DARI PESPEKTIF SEMIOTIKA
}

\author{
Chalarce Totanan * \\ Arista \\ Nina Yusnita Yamin \\ Muhammad Ikbal Abdullah \\ Muliati \\ Rahayu Indriasari \\ Universitas Tandulako, Soekarno Hatta km 9, Mantikulore, Palu, Indonesia \\ *chalarce@gmail.com
}

\author{
ARTICLE INFO \\ Article history: \\ Received March 7, 2021 \\ Revised November 15, 2021 \\ Accepted January 6, 2022
}

Key words:

Semiotic; Gender; Feminine; Masculinity; Machiavellian Practice

DOI:

https://doi.org/10.33508/jako.v14i1.3065

\begin{abstract}
A B S T R A C T
Research Purposes. The study aims is to analyze Machiavellian practices in accounting students based on gender by feminine and masculinity.

Research Method. This research based with Roland Barthes's semiotic paradigm. Data were obtained through interviews and involving themselves in the lecture and exam processes. Informants are accounting students were randomly selected.

Research Result and Findings. Machiavellian practice in denotation findings reveals that student actions are rule in written regulations, while the connotation reveals that the practice based on courage, solidarity, perfectionist and sensitivity level in carrying out the action of Machiavellian practices on accounting students. The meaning of myth in Barthes semiotics departs on the connotation meaning, where this study reveals that femininity and masculinity play a role for students in carrying out Machiavellian practices. The findings of this research, that when each student wants brilliant achievement so that he uses an improper method.
\end{abstract}

\section{A B S T R A K}

Tujuan Penelitian. Penelitian ini bertujuan untuk menganalisis praktik machiavellian pada mahasiswa akuntansi berdasarkan gender yaitu, feminitas dan maskulinitas.

Metode Penelitian. Metode penelitian ini mendasarkan pada paradigma semiotika Roland Barthes melalui tahapan denotasi dan konotasi. Data diperoleh melalui wawancara dan melibatkan diri dalam proses perkuliahan dan ujian. Informan adalah mashasiswa akuntansi yang dipilih secara acak.

Hasil dan Temuan Penelitian. Temuan memerlihatkan, dalam denotasi terungkap mahasiswa sadar tindakan dan hasil mereka telah diatur secara tertulis. Sedangkan, konotasi mengungkapkan praktik machiavellian didasari sifat keberanian, solidaritas, perfeksionis dan tingkat kepekaan dalam melakukan aksi yang tidak seharusnya. Makna mitos pada semiotika Barthes berangkat pada makna konotasi, dimana penelitian ini mengungkapkan bahwa feminitas dan maskulinitas memegang peran pada mahasiswa dalam melakukan praktik machiavellian. Temuan makna menjelaskan bahwa semakin mahasiswa dituntut dan menginginkan prestasi yang cemerlang akan cenderung menggunakan cara yang tidak seharusnya untuk memeroleh hasil yang baik.

\section{PENDAHULUAN}

Memiliki prestasi yang cemerlang merupakan impian setiap mahasiswa, berbagai usaha dapat ditempuh untuk memerolehnya. Mulai dari cara sehat hingga cara yang melanggar aturan-aturan yang ada. Paham machiavellian atau machiavellianis diperkenalkan oleh seorang filsuf politik dari Italia bernama Nicollo Machiavelli. Machiavellian atau machiavellianisme menjadi istilah yang memiliki konotasi negatif yang meliputi kelicikan, kecurangan, busuk dan tak bermoral. Akan tetapi 
secara umum sifat machiavellian tidak selamanya dianggap salah sebagai sesuatu yang negatif. Misalnya dalam dunia politik dan lingkup bisnis, strategi dan mempertahankan kekuasaan sejauh masih sesuai dengan peraturan yang ada maka masih layak dipraktikkan, sebaliknya penempatan pandangan tersebut diluar ranah politik masih diragukan. Sifat Machiavellian cenderung untuk mementingkan kepentingan sendiri, manipulatif dan agresif. Praktiknya yang diwarnai dengan pelanggaran aturan bertolak belakang dengan berbagai etika profesi, termasuk dalam proses perkuliahan dan penyelesaian studi (Shaleh, 2015; Suseno, 2020).

Salah satu profesi yang bertolak belakang dengan sifat Machiavellian adalah profesi akuntan. Standar profesional dan perilaku yang diatur dengan etika profesi menghalangi atau melarang perilaku jenis machiavellian (misalnya manipulasi dan oportunistik). Oleh karena profesi akuntan merupakan pekerjaan yang menuntut tanggung-jawabnya dengan standar profesionalisme, kompetensi yang tinggi, target kinerja tertinggi, dengan orientasi kepada kepentingan publik. Standar kerja ini harus dipertahankan untuk menjaga kepercayaan publik terhadap profesi akuntan (Hartman dan Desjardins, 2015). Meskipun gender tidak mempengaruhi literasi dalam akuntansi (Totanan,, Sudirman, Umiati, Yamin, Pakawaru dan Mile, 2020)

Mahasiswa akuntansi adalah seorang calon akuntan yang nantinya bisa mengisi posisi penting dalam perusahaan, pemerintahan, dan juga dalam profesi akuntan publik. Profesi ini sangat menuntut sikap integritas, yang artinya harus tegas dan jujur dalam semua keterlibatannya dalam hubungan profesional dan bisnis, tanpa sikap integritas yang dimliki oleh seorang akuntan bisa saja akuntan tersebut memanipulasi laporan keuangan sehingga menguntungkan satu pihak dan merugikan pihak yang lain (Rindayanti dan Budiarto, 2017). Jika mahasiswa melakukan tindakan pelanggaran yang ada guna untuk mencapai tujuannnya maka secara tidak langsung akan memupuk sifat curang dan menyalahi aturan.

Penelitian ini bertujuan untuk melihat praktik curang yang dilakukan mahasiswa dalam proses perkuliahan dan ujian demi memeroleh nilai baik. Peran gender dipercaya berpengaruh terhadap ketaatan terhadap aturan dan tingkat ambisi dari seseorang. Gender dalam penelitian ini menggunakan jenis kelamin sebagai indikator, meskipun gender bisa didefenisikan sebagai sifat maskulin dan feminim. Oleh karena itu masalah yang diangkat dalam penelitian ini adalah bagaimana praktik machiavellianism pada mahasiswa akuntansi dari pandangan semiotika.

Semiotika adalah suatu ilmu atau metode analisis untuk mengkaji tanda. Tanda-tanda adalah perangkat yang dipakai dalam upaya berusaha mencari jalan di kehidupan ini, di tengah-tengah manusia dan bersama dengan manusia (Totanan, 2021). Penelitian ini menggunakan semiotika Roland Barthes yang memfokuskan pada gambaran yang sangat kompleks mengenai produk masyarakatkebudayaan. Roland Barthes menjelaskan, bahwa makna memiliki standar ganda yang dimaknai sebagai makna denotasi, makna konotasi dan mitos.

Penelitian sebelumnya menunjukkan hasil yang bervariasi diantara Machiavellianism dan gender. Pada studi p opulasi umum, wanita secara umum memiliki skor rendah dalam skala Machiavelli dibanding pria (Christie dan Geis, 1970; Jones dan Paulhus, 2014). Namun demikian, ahli pemasaran wanita berdasarkan penelitian memiliki skor machiavellian yang lebih tinggi dari ahli pemasaran pria (Obalola, Aduloju dan Olowokudejo, 2012). Dalam hal tersebut gender bisa dikategorikan sebagai perangkat operasional dalam melakukan measure (pengukuran) terhadap persoalan laki-laki dan perempuan terutama yang terkait dengan pembagian peran. Menurut Giddens (2006) konsep gender menyangkut tentang "Psycological, social and cultural differences between males and females", yaitu perbedaan psikologis, sosial dan budaya antara laki-laki dan perempuan (Wood dan Eagly, 2002). Gender dapat mengidentifikasikan perilaku seseorang berdasarkan jenis kelamin, maka dalam hal ini sifat machiavellian dalam gender perlu diteliti, terutama semakin kuatnya issu gender dalam setiap profesi. Menggunakan analisis semiotika Roland Barthes bisa menjadi jembatan menemukan mitos gender dalam profesi akuntansi.

\section{KAJIAN LITERATUR DAN PENGEMBANGAN HIPOTESIS}

Kajian Literatur

Machiavellian dan Mahasiswa Akuntansi

Profesionalisme suatu profesi mensyaratkan tiga hal utama yang harus dipunyai oleh setiap anggota profesi tersebut, yaitu berkeahlian, berpengetahuan, dan berkarakter. Mahasiswa 
lulusan jurusan akuntansi sebagai calon akuntan harus memiliki tiga syarat tersebut agar berkemampuan profesionlisme yang tinggi untuk bisa menang dalam persaingan. Kode Etik Akuntan Indonesia (IAI, 2020) menyebutkan bahwa tujuan profesi akuntansi adalah memenuhi tanggungjawab dengan orientasi standar profesionalisme tertinggi, mencapai tingkat kinerja tertinggi dengan orientasi kepada publik. Kode Etik dimaksudkan sebagai panduan dan aturan bagi seluruh anggota.

Paham machiavellian diajarkan oleh seseorang ahli filsuf politik dari Italia bernama Nicollo Machiavelli. Nicollo merupakan seorang pemikir dan praktisi politik yang lahir pada 3 Mei 1489 di Florence, Italia dan berkembang menjadi seorang politikus dengan ide-ide yang konkret, praktis, dan peka terhadap prioritas-prioritas tindakan (Purnamasari, 2006). Machiavelli (1532) menjelaskan untuk meninggalkan pertimbangan moralitas yang menjadi kepedulian perilaku para penguasa (Mansfield, 2021). Penjelasan tersebut memiliki pandangan tentang manusia. Dia memandang manusia sebagai makhluk yang dikendalikan oleh kepentingan diri dan tingkah lakunya dipengaruhi oleh emosinya. Menurut Machiavelli dalam keadaan seperti seorang penguasa harus bisa mengendalikan tingkah laku rakyatnya.

Perilaku manusia sebagai suatu fungsi dari interaksi antara individu dengan lingkungannya, individu membawa tatanan dalam organisasi berupa kemampuan, kepercayaan pribadi, pengharapan, kebutuhan, dan pengalaman masa lainnya (Deddy dan Veithzal, 2012; Tandirerung, Totanan, Mile, Marsuddin dan Paranoan, 2019). Masing-masing individu memiliki karakteristik seperti kemampuan, kepercayaan pribadi, harapan kebutuhan, dan pengalaman masa lalunya. sikap yang ada pada seseorang akan memberikan warna atau corak pada perilaku atau perbuatan orang yang bersangkutan (Jensen dan Meckling, 1976; Nash, 2002). Akan tetapi banyak contoh perilaku mahasiswa akuntansi yang mencermikan praktik machiavellian. Mulai dari menyelesaikan tugas dengan menyontek, menitip kehadiran pada teman pada saat kuliah sampai melobi pihak tertentu untuk penentuan nilai. Robbins (2015) serta Robbins dan Judge (2017) mendefinisikan machiavellian sebagai tingkat di mana seseorang individu pragmatis, mempertahankan jarak emosional, dan yakni bahwa hasil lebih penting dari proses. Sifat machiavellian ini merupakan sifat yang memiliki dampak buruk bagi mahasiswa akuntansi sebagai calon akuntan, karena seseorang yang menganut sifat machiavellian akan cenderung memiliki sifat manipulatif dalam kehidupannya.

\section{Gender}

Konsep gender berbeda dengan jenis kelamin, meskipun secara etimologis artinya sama sama dengan sex, yaitu jenis kelamin. Secara umum sex digunakan untuk mengidentifikasi perbedaan laki-laki dan perempuan dari segi anatomi biologis. Studi sex lebih menekankan kepada perkembangan aspek biologis dan komposisi kimia dalam tubuh seorang laki-laki dan seorang perempuan, maka studi gender lebih menekankan kepada perkembangan aspek maskulinitas dan femininitas seseorang.

Pada dasarnya feminitas dan makulinitas yang dianggap sebagai pertentangan dalam gender ini bersifat abstrak, dan sifat ini dapat dimiliki oleh siapa saja. Namun ada beberapa hal yang telah dikategorikan dalam bentuk feminitas dan maskulinitas serta dikotomi dan dihirarkikan, contohnya feminin adalah kepekaan perasaan, kesabaran, kelembutan, irrasionalitas, kesetian, sifat mengalah dan lemah. Sebaliknya, yang digolongkan sebagai maskulin adalah keberanian, agresifitas, sifat dominan, rasionalitas, ketidak setiaan, dan kekuatan (Fakih, 2012).

\section{Machiavellian dan Gender}

Gender akan menentukan seksualitas, hubungan dan kemampuan kita untuk membuat keputusan dan bertindak secara otonom, dari pemahaman tersebut gender memegang peran penting dalam mempengaruhi perilaku seseorang dalam berbagai aspek, begitupun perilaku baik atau buruknya mahasiswa dalam mencapai tujuannya. Sifat yang menghalalkan segala cara demi mencapai tujuan atau keinginan merupakan sifat machiavellian.

Feminin merupakan ciri-ciri atau trait yang dipercaya dan dibentuk oleh budaya sebagai ideal bagi perempuan. Sedangkan maskulin adalah ciriciri yang berkaitan dengan peran gender yang lebih umum dimiliki oleh laki-laki, atau suatu peran atau trait maskulin yang dibentuk oleh budaya. Sifat maskulinitas adalah sifat yang dipercaya dan dibentuk oleh budaya sebagai ciriciri yang ideal bagi laki-laki. Sifat yang menonjolkan perilaku ingin memimpin, penginisiatif, dan melindungi. Kebudayaan Indonesia memerlihatkan maskulinitas masih cenderung mendominasi berbagai profesi dan 
juga tingkat peran dalam pengambilan keputusan. Di samping itu praktik kejahatan akan terlihat lebih jahat jika dilakukan oleh perempuan jika dibandingkan oleh laki-laki. Hal ini didasarkan bahwa wanita seharusnya lebih suci dibandingkan dengan laki-laki, termasuk dalam tindakan. Dalam penelitian ini, peran gender maskulin dan feminim inilah yang digunakan melihat perbedaan praktik machiavellian yang terdapat dalam diri individu mahasiswa.

\section{Tanda dan Makna}

Manusia pada dasarnya hidup pada dunia tanda yang memengaruhi cara-caranya bertindak dan berperilaku. Tanda merupakan sesuatu yang bersifat fisik dan bisa dipersepsi indra kita. Tanda mengacu pada sesuatu diluar tanda tersebut dan bergantung pada pengamatan oleh penggunaannya sehingga bisa disebut tanda (Suprapto, 2009). Umberto Eco (dalam Wibowo, 2013) menyebutkan bahwa tanda adalah suatu kebohongan, dan dalam tanda ada sesuatu yang tersembunyi di baliknya dan bukan tanda itu sendiri. semua kehidupan manusia dilingkupi dengan tanda.

Tanda memiliki dua dimensi yaitu, bentuk fisik dari tanda itu sendiri berupa bentuk ekspresi individu (kata-kata, suara, ataupun simbol), dan dimensi makna yaitu isi dari sebuah tanda itu sendiri. Menurut McQuail (2011), tanda adalah setiap kesan bunyi yang berfungsi sebagai signifikasi. Ini berarti tanda adaalh suatu objek atau konsep dalam dunia pengalaman yang ingin dikomunikasikan. Dari beberapa penjelasan diatas dapat merujuk bahwa tanda merupakan sebuah objek nyata yang dapat diindrakan dan memiliki maksut didalamnya yaitu makna.

Tanda akan menghasilkan persepsi makna bagi yang melihat, mendengar, dan merasanya. Makna ialah hubungan suatu objek atau ide dan suatu tanda (Suprapto, 2009) Sobur (2009) menyatakan bahwa makna merupakan kecenderungan total untuk menggunakan atau beraksi terhadap suatu bahasa. Makna terletak pada manusia bukan pada kata-kata, kata-kata digunakan untuk mendekati makna. Asumsiasumsi yang dikemukakan Johnsons menitik beratkan bahwa makna itu berada pada diri manusia tersebut dan dapat berubah tergantung keadaan budaya, ekonomi, sosial, politik, daerah, dan individu yang menggunakannya

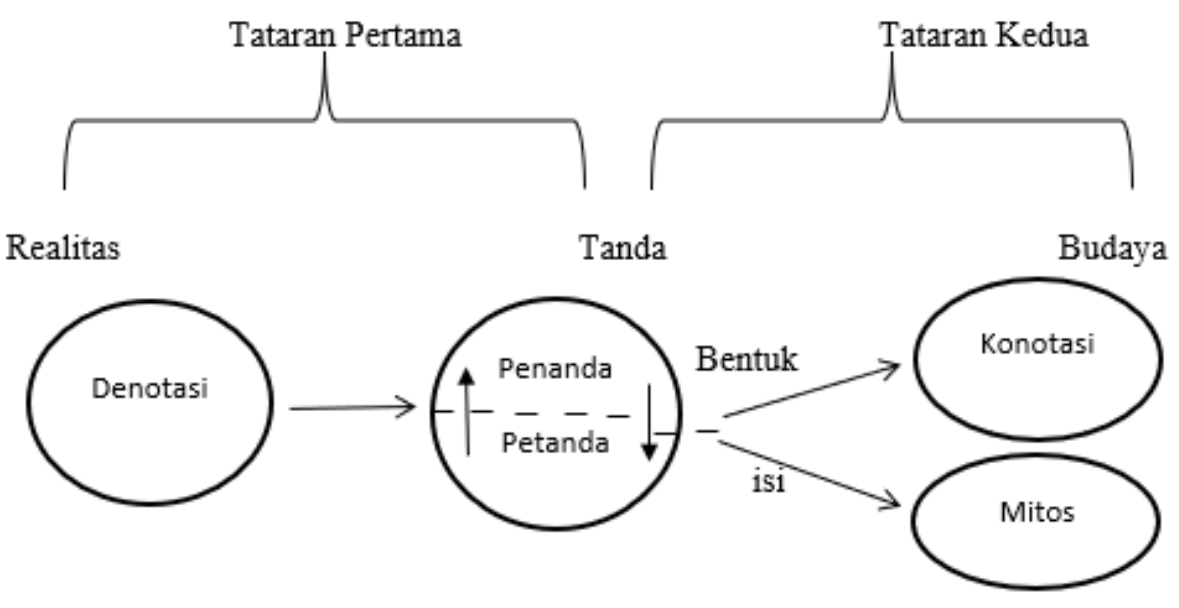

Gambar 1. Signifikasi Dua Tahap Barthes

Semiotika dalam arti modern berangkat dari Ferdinand de Saussure (1857-1913) dan filsuf Amerika Charles Sander Pierce (1839-1914). Salah seorang pengikut Saussure, Roland Bartes, membuat sebuah model sistematis dalam menganalisis sistem makna dari tanda-tanda. Fokus perhatian Barthes lebih tertuju kepada gagasan tentang signifikasi dua tahap (two order of signification) seperti terlihat pada gambar 1 .

Melalui gambar tersebut Moleong (2015) dan Zubair (2013), Barthes menjelaskan signifikasi tahap pertama merupakan hubungan signifier dan signified didalam sebuah tanda terhadap realitas eksternal. Barthes menyebutkan sebagai denotasi, yaitu makna yang paling nyata dari tanda. Konotasi adalah istilah yang digunakan Barthes untuk menunjukan signifikasi tahap kedua. Hal 
ini menggambarkan interaksi yang terjadi ketika tanda bertemu dengan perasaan atau emosi pembaca serta nilai-nilai dari kebudayaan. Konotasi memiliki makna yang subjektif atau paling tidak intersubjektif.

Pada signifikasi tahap kedua yang berhubungan dengan isi, tanda bekerja melalui mitos (myth). Mitos adalah bagaimana kebudayaan menjelaskan atau memahami beberapa aspek tentang realitas atau gejala alam. Mitos merupakan produk kelas sosial yang sudah mempunyai suatu dominasi (Zubair, 2013).

\section{Semiotika Roland Barthes}

Dalam penelitian ini menggunakan pandangan studi komunikasi yang menyatakan bahwa komunikasi sebagai proses pertukaran dan produksi makna melalui sebuah tanda atau simbol. Sehingga pemaknaan (signifikasi) dijadikan sebuah ujung tombak dalam melakukan penelitian pada mahasiswa akuntansi yang melakukan praktik Machiavellian dalam mencapai tujuannya berdasarkan gender. Metode utama untuk paham ini yaitu semiotika. Semiotika merupakan suatu model dari ilmu pengetahuan sosial, yang memahami dunia sebagai sistem hubungan yang memiliki unit dasar yang disebut 'tanda' (Sobur, 2009).

Penelitian Semiotika tidak begitu saja melepas nama Roland Barthes (1915-1980) ahli semiotika yang mengembangkan kajian yang sebelumnya punya warna kental strukturalisme kepada semiotika teks (Wibowo, 2013). Lewat model ini Barthes menjelaskan bahwa signifikasi tahap pertama merupakan hubungan antara signifier (ekspresi) dan signified (content) didalam sebuah tanda terhadap realitas eksternal. Hal itu yang disebut Barthes sebagai denotasi yaitu makna paling nyata dari tanda (sign). Konotasi adalah istilah yang digunakan Barthes untuk menunjukkan signifikasi tahap kedua. Hal ini menggambarkan interaksi yang terjadi ketika tanda bertemu dengan perasaan atau emosi dari pembaca serta nilai-nilai dari kebudayaan. Konotasi mempunyai makna yang subjektif atau paling tidak inter subjektif. Dengan kata lain, denotasi adalah apa yang digambarkan tanda terhadap sebuah objek, sedangkan makna konotasi adalah bagaimana cara menggambarkannya.

Pada signifikasi tahap kedua, tanda bekerja melalui mitos (myth). Mitos adalah bagaimana kebudayaan menjelaskan atau memahami beberapa aspek tentang realitas atau gejala alam. Mitos merupakan produk kelas sosial yang sudah mempunyai suatu dominasi. Mitos Primitif, misalnya mengenai hidup dan mati, manusia dan dewa. Sedangkan mitos masa kini misalnya mengenai feminimitas, maskulinitas, ilmu pengetahuan dan kesuksesan.

Oleh karena kekhasan penelitian kualitatif sehingga sebelum masuk dalam pembahasan diperlukan penjelasan awal yang bertujuan untuk memberi pemahaman mengenai konsep-konsep dalam penelitian ini. Agar tidak terjadi kesalahan penafsiran, maka berikut ini adalah batasanbatasan dari istilah-istilah tersebut:

1. Representasi adalah penggambaran, meniru, atau mewakili sesuatu hal yang terhadap hal yang lain. Representasi pada penelitian ini merupakan upaya penggambaran praktik Machiavellian pada mahasiswa akuntansi sebagai objek yang diteliti.

2. Praktik Machiavellian adalah perilaku yang dilakukan oleh mahasiswa akuntansi universitas tadulako yang dianggap tidak sesuai sistem dan aturan yang berlaku secara akademik.

3. Semiotika Roland Barthes adalah analisis atau model yang digunakan oleh penelitian ini untuk mendapatkan representasi bentuk tanda-tanda dari praktik Machiavellian mahasiswa akuntansi Universitas Tadulako. Model semiotika Roland Barthes terdiri dari yaitu: (a) Denotasi adalah makna sebenarnya atau makna pertama dari praktik Machiavellian yang dilakukan mahasiswa akuntansi Universitas Tadulako; (b) Konotasi adalah makna kedua atau makna bias yang dipengaruhi oleh konstruksi gender; dan (c) Mitos adalah sistem makna dalam aspek tentang realitas dan kebudayaan sehingga berwujud pada sistem nilai yang memengaruhi adanya praktik Machiavellian dikalangan mahasiswa akuntansi Universitas Tadulako. Pengukuran Feminitas dan Maskulinitas pada penelitian ini dengan cara mendeskripsikan informan dengan melihat karakteristik peran gender yang telah dijelaskan sebelumnya.

\section{METODE PENELITIAN}

Penelitian ini merupakan jenis penelitian kualitatif yang dilakukan untuk memberikan gambaran secara jelas mengenai objek penelitian sehingga dapat menjawab setiap permasalahan 
yang terjadi dengan menekankan pada kualitas. penelitian kualitatif deskriptif berusaha menjawab apa penjelasan lebih terperinci mengenai gejala sosial seperti yang dimaksutkan dalam permasalahan penelitian. Melalui penelitian deskriptif peneliti berusaha memahami sebuah praktik Machiavellian dengan sudut pandang yang berbeda untuk menemukan makna yang ada dibalik tindakan tersebut.

Penelitian ini menggunakan observasi partisipan dan wawancara. Observasi partisipan yang dilakukan oleh peneliti dengan cara get in kedalam kelas ujian dan juga berperan menjadi salah satu peserta ujian. Hal ini dilakukan untuk memotret perilaku mahasiswa dalam mengikuti ujian guna keperluan penelitian. Peneliti meminta izin kepada dosen pengawas untuk bisa get in dalam kelas ujian. Masuk dalam kelas dan berperan mengikuti ujian dilakukan sebayak tiga kali dalam tiga kelas berbeda. Wawancara dilakukan dengan mahasiswa dari yang terpilih secara accidental.

Hasil dari proses observasi partisipan dan wawancara kemudian dianalisis menggunakan Semiotika Roland Barthes dengan empat tahapan pengungkapan makna yakni, makna denotasi, konotasi dan mitos. Model ini berasumsi pembentukan kalimat dan cara bentuk-bentuk kalimat menentukan makna, tetapi kurang tertarik pada kenyataan bahwa kalimat yang sama bisa saja menyampaikan makna yang berbeda pada orang yang berbeda situasinya. Roland Barthes meneruskan pemikiran tersebut dengan menekankan interaksi antara teks dengan pengalaman personal dan kultural penggunaanya, interaksi antara konvensi dalam teks dengan konvensi yang dialami dan diharapkan oleh penggunannya (Kriyantono, 2009; Totanan, 2021).

Simbol-simbol yang ada pada praktik machiavellian sebagai tanda adalah perilaku dan gender. Makna-makna yang diperoleh dari pendekatan ini diharapkan dapat merepresentasikan bahkan memahami realitas sosial atau perilaku yang coba dimunculkan dalam kehidupan sehari-hari. Oleh sebab itu semiotika relevan dalam mengurai makna-makna praktik machiavelian yang dilakukan oleh mahasiswa akuntansi.

\section{$\frac{\text { Triangulasi Data }}{\text { Peneitan }}$}

Penelitian ilmiah tidak lepas dari kepercayaan orang akan proses penelitian dan hasilnya. Penelitian dikatakan ilmiah bila mengandung tingkat obyektivitas yang tinggi dan ini akan meningkatkan kepercayaan masyarakat pada hasilnya (Satori dan Komariah, 2013). Sugiyono (2012) menjelaskan uji keabsahan data dalam penelitian kualitatif meliputi uji Credibility (kepercayaan), transferability (keteralihan), dependability (kebergantungan), dan confirmability (obyektivitas). Penelitian ini melakukan uji kepercayaan terhadap data hasil penelitian melalui triangulasi. Peneliti melakukan trianggulasi sumber yang terlibat langsung dalam praktik machiavellian dan trianggulasi waktu dengan melakukan get in pada tiga kelas dalam waktu ujian yang berbeda.

\section{Pengumpulan Data}

Sumber data yang digunakan dalam penelitian ini berasal dari informan. Informan yang dimaksud adalah key informant seperti yang dijelaskan oleh (Moleong, 2015), yaitu informan yang tidak hanya memberi keterangan tentang sesuatu kepada penelitian tetapi juga dapat memberi saran tentang sumber bukti yang mendukung serta menciptakan sesuatu terhadap yang bersangkutan.

Teknik penentuan informan pada penelitian ini yaitu accidental sampling. (Sugiyono, 2018) menjelaskan teknik jenis sampel ini adalah teknik penentuan sampel berdasarkan kebetulan, yaitu siapa saja yang secara kebetulan/aksidental bertemu dengan peneliti dapat digunakan sebagai sampel, bila dipandang orang yang kebetulan ditemui cocok sebagai sumber data. Ada tujuh orang sebagai informan dalam penelitian ini yang dipilih secara accidental dan acak. Jumlah tujuh informan dipandang sudah mewakili dari tiga kelas ujian yang menjadi situs pengamatan. Pemilihan tujuh orang informan secara acak dilakukan karena sifat machiavellian bisa ada pada setiap mahasiswa. Situs dalam penelitian ini adalah tempat atau wilayah dimana penelitian tersebut akan dilakukan. Situs dalam penelitian adalah Jurusan Akuntansi Universitas Tadulako.

\section{HASIL DAN PEMBAHASAN}

Pembahasan dilakukan sesuai dengan prinsip semiotika dua tahap dari Roland Barthes. Tahap pertama adalah menemukan tanda dan denotasi. Pada tahap kedua menemukan konotasi yang selanjutnya akan menghasilkan mitos yang menjadi budaya massa. 
Praktik Machiavellian

Praktik Machiavellian yang dikenal memudahkan dalam mencapai tujuan menjadi pilihan mahasiswa. Dalam konteks penelitian sebagaimana telah diuraikan pada prolog, segala bentuk praktik machiavellian yang telah dilakukan mahasiswa selalu menjadi pilihan ketika dihadapkan dengan kesempatan dan tujuan yang mahasiswa ingin capai. $\mathrm{M}$ mengungkapkan pendapatnya mengenai praktik Machiavellian yang dilakukan.

"Saya menyontek karena pengawasan longgar, dosen hanya duduk didepan baca buku atau main laptop dan itu kesempatan buat saya dengan mudah menyelesaikan ujian dengan membuka hp atau melihat catatan"

Mahasiswa dengan segala tuntutan dihadapkan dengan kesempatan yang ada, besar kemungkinan mereka akan melakukan apapun tanpa memperdulikan kode etik sebagai mahasiswa. Pada proses get in yang dilakukan peneliti juga menarik kesimpulan bahwa ketika pengawasan ketat mahasiswa yang ikut ujian akan menyiapkan dirinya dengan belajar dengan baik karena mereka sadar jika pada saat ujian tidak akan memiliki kesempatan menyelesaikan ujian dengan curang karena pengawasan yang ketat. Metode ujian juga mempengaruhi bentuk kecurangan yang dilakukan mahasiswa. Semakin mereka diawasi atau model ujian dengan diberikan batasan waktu untuk menjawab menekan mahasiswa dalam proses menyontek. Oleh karena batasan waktu tersebut yang membatasi akses atau peluang mahasiswa untuk menyontek. M menekankan pernyataan diatas.

"Jika saya sudah tau dosen mata kuliah yang mengawas disiplin dan tegas pasti saya belajar atau saat ujian saya usahakan isi sendiri saja apapun itu yang penting hasil sendiri, karena kalau berani melakukan dengan pengawasan ketat bukannya lulus malah tidak lulus"

Berdasarkan uraian diatas segala bentuk kecurangan yang dilakukan mahasiswa didorong dari berbagai hal seperti kesempatan yang ada dan dapat ditekan jika segala aspek yang bersangkutan ikut berperan didalamnya. Dalam konteks yang berbeda, Salah satu informan yang peneliti temui dalam setiap kesempatan yaitu A mengungkapkan melakukan kecurangan karena dosen pada saat mata kuliah hanya sebatas penggugur kewajiban.
"Saya titip absen karena dosen yang masuk tidak mengabsen kembali atau tidak mengecek kehadiran dan kadang dosen tidak hadir cuman disuruh diskusi tapi mengisi kehadiran dari pada jauh ke kampus mending titip absen"

Terlihat bahwa peluang dan kesempatan adalah penentu praktik Machiavellian dipilih atau tidak. Motivasi dan kesempatan mahasiswa yang begitu kuat untuk berhasil mencapai tujuannya adalah pendorong praktik ini dianggap sebagai alternatif bagi mahasiwa. Machiavellian tidak akan menjadi pilihan jika praktik ini tidak bekerja untuk mencapai tujuan. Hal ini semakin menegaskan bahwa peluang adalah pertimbangan utama praktik ini diterapkan oleh mahasiswa. Teori fraud triangle memperjelas temuan di atas. Fraud triangle membahas hal terkait dengan dorongandorongan yang menyebabkan orang melakukan kecurangan atau fraud. Dalam teori tersebut menjelaskan tiga factor yang hadir dalam setiap situasi kecurangan yaitu pressure (tekanan), opportunity (kesempatan) dan yang terakhir adalah rationalization (rasionalisasi).

Temuan Hasil Denotasi dan Konotasi Praktik Machiavellian Mahasiswa

Temuan-temuan yang telah dihasilkan oleh peneliti lewat analisis sebuah praktik machiavellian yang dilakukan mahasiswa akuntansi dalam pencapaian akademik dan peneliti akan mengaitkan temuan dari praktik yang dilakukan mahasiswa ke dalam karakteristik dari feminitas dan maskulinitas yang ada pada mahasiswa akuntansi. Demikian hasil temuan tersebut dapat peneliti jelaskan dan disebutkan pada bagian berikut berdasarkan perangkat semiotika Roland Barthes yaitu denotasi dan konotasi. Pada makna denotasi menggambarkan praktik machiavellian yang dilakukan mahasiswa dalam kehidupan dunia kampus dalam mencapai segala tujuannya yang diasumsikan sebagai makna tunggal dan makna konotasi menggambarkan praktik machiavellian mahasiswa akuntansi dalam bentuk penilaian yang berbeda oleh setiap individu yang dipengaruhi feminitas dan maskulinitas.

\section{Denotasi}

Mahasiswa yang dituntut meningkatkan kualitas mendorong mahasiswa melakukan atau mengikuti tuntutan tersebut, dengan mulai dari giat belajar, rajin mengikuti perkuliahan, aktif dalam bidang organisasi dan hal yang menujang 
dalam proses pembelajaran seperti kerja kelompok dan hal lainnya yang berkaitan sampai dengan menghalalkan segala cara yang tidak seharusnya menjadi keputusan untuk dilakukan, contohnya praktik menyontek dan titip absen dalam hal memenuhi atau memalsukan hasil dari ujian yang dilakukan mahasiswa.

Makna denotasi merupakan tingkat penandaan yang menghubungkan antara penanda dan petanda yang menghasilkan makna eksplisit, langsung dan pasti. Denotasi adalah tanda yang penandanya mempunyai tingkat konvensi atau kesepakatan yang tinggi. Secara denotasi praktik yang dilakukan mahasiswa akuntansi adalah pelanggaran etika atau aturan yang berlaku. Berdasarkan wawancara yang dilakukan, peneliti mendapatkan ungkapan mahasiswa yang memperjelas hal di atas yaitu informan $\mathrm{H}$ yang mengatakan bahwa:

"Menyontek adalah tindakan yang tidaklah benar, menyontek merupakan tindakan yang tidak seharusnya dilakukan karena itu adalah perbuatan yang menipu"

Begitupun pada praktik titip absen yang dilakukan mahasiswa atau lebih tepatnya titip presensi adalah tindakan mahasiswa yang bertujuan untuk memanipulasi daftar presensinya untuk kepentingan pribadi dengan cara menitipkan presensinya kepada teman sekelasnya yang (sekiranya) hadir dalam suatu mata kuliah. Praktik ini juga merupakan tindakan yang tidak etis yang mahasiswa lakukan karena menipu pihak tertentu.

Pada penjelasan diatas dapat disimpulkan bahwa tindakan menyontek dan titip absen yang dilakukan oleh mahasiswa adalah tindakan yang tidak etis, mahasiswa dengan segala aturan yang ada seharusnya tidak melakukan hal tersebut. Salah satu informan U juga mengungkapkan pendapatnya mengenai bagaimana mahasiswa seharusnya:

"Mahasiswa itu lebih tinggi dari pelajar, karena mahasiswa kan lebih pandai berpikir.Menurut saya melihat dari pola pikir dan tindakan, dan mengubah mendset dari mahasiswa itu sendiri karena mahasiswa itu harusnya bertindak sesuai etika yang berlaku dimasyarakat ataupun dimana dia berada"

Berdasarkan pendapat informan diatas bahwa mahasiswa telah diatur dalam aturan yang berlaku dan seharusnya menaati aturan tersebut, dengan melanggar aturan yang ada dapat dikatakan bahwa mahasiswa tersebut berperilaku tidak etis dan tidak semestinya bagaimana mahasiswa berperilaku dan bertindak.

\section{Konotasi}

Get in yang dilakukan peneliti pada saat melakukan observasi menghasilkan temuan yang merupakan bentuk dan tanda mahasiswa dalam melakukan kecurangan atau praktik Machiavellian dalam menyelesaikan hasil ujian dengan mudah dan lulus dalam ujian tersebut. Pada ujian mahasiswa akuntansi angkatan 2018, mahasiswa sudah mengatur segala strategi dalam melakukan tindakan kecurangan. Dilihat dari pemilihan tempat, mahasiswa akan memilih teman yang sudah memiliki ikatan emosional ataupun duduk dengan teman yang mereka anggap mampu menyelesaikan ujian dengan baik. Pengamatan yang dilakukan peneliti didukung pernyataan informan A yaitu:

"Jika besok saya akan ujian mata kuliah yang saya tidak mengerti pasti saya cepat datang memilih tempat yang tidak diliat sama dosen dan pasti saya carikan tempat juga temanku supaya nanti dia bantu saya saat ujian jika saya sudah menyerah mengerjakan"

Mahasiswa yang melakukan segala praktik kecurangan merupakan hal yang biasa di kalangan mahasiswa, mereka mengungkapkan bahwa praktik ini tidak begitu perlu dipermasalahkan karena hal ini tidak begitu merugikan mahasiswa lain jika mereka melakukannya. Mahasiswa beranggapan praktik ini bisa saling menguntungkan kedua belah pihak contohnya praktik titip absen. Informan $\mathrm{V}$ mengungkapkan demikian :

"Biasa kalau titip absen saya lakukan karena ada urusan, kadang temanku yang titip absen sama saya jadi pas saya yang titip absen dia juga mau rasa saling membantulah. Cuman ada temanku juga sudah sering begitu saya rasa dia malas atau tidak suka mata kuliah itu"

Pandangan lain diberikan informan $M$ yaitu: "Titip absen sering saya lakukan awal kuliah, karena saya tidak tau kalau titip absen itu tidak diperbolehkan, karena saya pikir tidak mengapa kalau tidak hadir baru diabsenkan. Saya pikir titip absen itu kan cuman syarat untuk ujian jadi kasian kalau misalnya teman atau saya sendiri tidak ikut ujian karena saya tidak cukup kehadiran" 
Segala pernyataan yang dikatakan oleh informan cukup menekankan bahwa mahasiswa tidak begitu mempermasalahkan praktik kecurangan yang mereka lakukan. Mahasiswa menganggap kecurangan yang mereka lakukan adalah bentuk solidaritas sebagai mahasiswa. Pernyataan ini disetujui oleh informan $\mathrm{H}$ :

"Saya sama teman saya sama-sama masuk kuliah jadi usahakan sama-sama keluar, samasama sukses jadi kalau dia minta bantuan usahakan dibantu"

Segala tindakan kecurangan yang dilakukan mahasiswa, merupakan tindakan yang dikatakan berani, karena hal ini adalah tindakan yang memiliki konsekuensi yang akan didapatkan, peneliti menyimpulkan mahasiswa yang melakukan adalah mahasiswa yang memiliki keberanian yang cukup dalam melakukan hal tersebut, pernyataan ini didukung oleh salah satu informan A, yang mengatakan bahwa:

“...sewaktu saya menyontek yang harus saya miliki itu rasa berani, kalau kau tidak berani melakukan menyontek jangan sekali-kali dilakukan karena pasti akan ketahuan"

Tindakan kecurangan yang dilakukan mahasiswa tidak hanya didasari keberanian banyak hal yang dimiliki mahasiswa dalam melakukan aksi kecurangan, seperti halnya keegoisan, kemalasan, kehati-hatian, dan solidaritas yang mereka miliki menjadi hal yang mendorong mereka melancarkan aksi kecurangan tersebut.

Dalam proses get in yang peneliti lakukan menemukan bentuk kecurangan yang berbeda sesuai dengan pengawasan yang mahasiswa dapatkan, jika mahasiswa merasa pengawasan longgar mereka akan mengisyaratkan temannya untuk memberikan jawaban atau bertukar jawaban dengan menggunakan kode-kode yang telah mereka sepakati. Sedangkan dalam hal pengawasan ketat mahasiswa yang ingin melancarkan kecurangan demi lulus ujian mereka akan memilih melakukan alat bantu (Handphone) atau sejenisnya, dalam aksi ini mereka melakukannya secara individu dengan keberanian dan kehati-hatian yang mahasiswa miliki. Informan $\mathrm{V}$ memperkuat temuan peneliti dengan mengungkapkan bahwa:

"Pertama mereka yang ingin melakukan kecurangan dia gelisah, melihat kesana kemari seperti melihat situasi dan menangkap tatapan mata teman-temannya supaya merasa dikasihani, melihat posisi dosen sama biasanya kalau mahasiswa menyontek lewat
HP biasanya melihat kebawah, kalau saya tidak menggunakan HP tidak berani karena lebih susah jadi mending tanya sama teman yang pintar"

Tindakan kecurangan yang dilakukan mahasiswa merupakan hal yang mengacu emosional mahasiswa terlihat dari pendapat iniforman di atas. Segala kecurangan yang dilakukan mahasiswa memerlukan keberanian dan segala hal pendungkung dikarenakan mahasiswa sadar dan paham dengan konsekuensi yang meraka hadapi dengan tindakan mereka.

Makna Mitos pada Mahasiswa Akuntansi dalam Praktik Machiavellian

Sistem pemaknaan Roland Barthes bahwa budaya atau peranan gender akan selalu berhubungan dan bersinergi dengan mitos-mitos perilaku keseharian manusia begitupun mahasiswa dalam lingkup dunia kampus. Pada tahap denotasi praktik Machiavellian dilakukan oleh mahasiswa sebagai tindakan atau kebiasaaan yang telah mereka lakukan dan tidak menjadi permasalahan dikalangan mahasiswa dikarenakan segala peluang dan keuntungan yang mereka peroleh. Selanjutya tahap konotasi dari praktik Machiavellian yang dilakukan mahasiswa akuntansi telah dijelaskan oleh peneliti sebelumnya, dimana pada tahap konotasi praktik Machiavellian dilakukan mahasiswa sebagai bentuk penyelesaian tujuan akademik. Tahap ini peneliti menemukan bahwa aksi dari praktik Machiavellian didasari dari berbagai sifat yang ada pada mahasiswa yang mana sifat tersebut adalah keberanian, solidaritas dan tingkat kepekaan dalam melihat situasi guna melancarkan aksi mahasiswa dalam tindakan kecurangan.

Sesuai dengan semiotika Barthes, mitos berangkat pada tingkat kedua atau tingkat konotasi yang akan memunculkan ideologi baru. Tahap konotasi pada penjelasan sebelumnya menjelaskan sifat yang mendasari mahasiswa melakukan praktik Machiavellian. Sifat tersebut merupakan gender-non biologis atau sifat feminitas dan maskulinitas. Dalam menghubungkan gender pada praktik Machiavellian peneliti akan menjelaskan melalui penemuan dari makna konotasi yaitu penemuan sifat yang ada dalam karakteristik feminitas dan maskulinitas.

Sifat feminin yang ada pada mahasiswa berperan penting dalam melakukan kecurangan akademik. Hal ini terdapat pada salah satu sifat 
feminin yaitu kepekaan. Dalam konteks ini kepekaan yang dimaksudkan adalah bagaimana dan kapan mahasiswa akan melakukan kecurangan dengan melihat situasi yang ada dalam melakukan aksi tersebut. Salah satu contoh yang peneliti temukan di lapangan bahwa sifat feminin sangat ahli pada aksi ini, yaitu pada isyarat non verbal yang mereka lakukan pada kecurangan menyontek pada saat ujian. Dimana mereka akan menggunakan isyarat atau kode yang telah mereka sepakati bersama guna memudahkan mereka dalam memberi dan mendapatkan jawaban ujian. Pada salah satu informan $\mathrm{M}$ memperkuat temuan peneliti yang mengatakan.

"...Ya, pakai bahasa tubuh saja kaya tatapan
atau kode tertentu, sebenarnya menyontek
pilihan ganda lebih muda karena gampang
memberikan kode. Karena pasti saya dengan
teman sudah ada kode-kode yang kita buat"

Peneliti juga menyimpulkan sifat feminitas lebih mendominan aksi mahasiswa yang meghalalkan segala cara dalam pencapaiannya. Hal ini dikarenakan perfectionist yang dimiliki pada karakteristik feminitas. Disaat mereka berada dalam keadaan ingin memenuhi segala tujuan mereka seperti apa yang telah mereka pikirkan sedemikian rupa akan tetapi di suatu kondisi hal kecurangan harus dilakukan agar segala keinginan yang mereka ingin capai menjadi nyata. Pemikiran feminitas yang ingin selalu mendapatkan hal yang sempurna memaksakan mereka melakukan tindakan apapun guna untuk mencapai segala harapan yang mereka miliki. A mengakui adanya pilihan yang muncul saat ingin memenuhi keinginannya.

"Dari semester awal IPK saya sudah tinggi jadi seharusnya semester-semester berikutnya harus tinggi juga, jadi ada saat saya ujian saya tidak tau saya harus menyontek atau hal lainnya supaya ujian saya terisi dengan baik dan lulus supaya saya pastikan nanti IPK saya stabil atau naik"

Pemenuhan standar nilai yang mahasiswa inginkan menjadi salah satu penunjang mereka melakukan segala tindakan yang tidak etis. Dari segala temuan mengenai feminitas dan tindakan kecurangan yang dilakukan, tidak serta-merta sifat maskulin tidak berperan dalam tindakan menghalalkan segala cara dalam pemenuhan tujuan akademik. Karakteristik maskulinitas yaitu keberanian menjadi awal aksi kecurangan terjadi.
Dalam hal keberanian memiliki dua makna konotasi yaitu positif dan negatif. Akan tetapi, pada penelitian ini keberanian berkonotasi negatif dikarenakan dalam hal ini mahasiswa rela menanggung segala konsekuensi yang mereka dapatkan dalam keadaan apapun dari tindakan tidak etis yang mereka lakukan demi suatu pencapaian. A mengungkapkan demikian:
"...Disaat ujian berlangsung saya menyontek karena saya tidak tau lagi jawabannya, ini saya lakukan supaya ujianku juga sempurna. Menyontek itu mudah dilakukan disaat kau berani dan tidak ada keraguan dalam dirimu (tertawa)"

Selain keberanian yang dimiliki dari maskulinitas, solidaritas juga berperan dalam melakukan kecurangan yang mana hal tersebut dimiliki dari sifat maskulin. Hal ini juga menjadi temuan yang banyak peneliti temukan pada saat dilapangan. Mahasiswa beranggapan mereka adalah saudara yang seharusnya saling membantu dalam keadaan apapun. Seperti apa yang telah peneliti tuliskan pada makna konotasi sebelumnya. Akan tetapi kesimpulannya hal ini hanya suatu alasan yang mereka buat, karena pada dasarnya mereka melakukan ini dikarenakan segala keuntungan yang mereka peroleh. Seperti yang dikatakan V pada saat wawancara.

"Titip absen yang saya lakukan karena ada urusan, kadang temanku yang titip absen sama saya, jadi nanti kalau saya yang titip absen pasti dia mau, karena saling membantu, urusan selesai mata kuliah aman"

Segala temuan yang diperoleh di atas peneliti menyimpulkan bahwa feminitas dan maskulinitas yang ada pada mahasiswa dalam melakukan tindakan tidak etis atau kecurangan dalam pencapaian akademik sangat berperan dan turut andil menyukseskan segala kecurangan. Akan tetapi, mahasiswa dengan sifat feminin cenderung lebih tinggi dalam melakukan kecurangan akademik di banding sifat maskulin. Hal tersebut dapat dilihat dari temuan dan penjelasan sebelumnya. Sifat maskulin juga memegang andil tersendiri pada mahasiswa dalam melancarkan aksi kecurangan, seperti dorongan keberanian untuk berbuat curang.

Perspektif ini menjelaskan bahwa gender mempunyai beberapa implikasi penting. Pertama, gender secara inheren bersifat maskulin dan feminin, yang terdapat dalam setiap individu mahasiswa. Sistem pemaknaan Roland Barthes 
menjelaskan gender merupakan mitos yang disebut myth. Kemudian praktik machiavellian pada mahasiswa disebut dengan budaya ataupun kebiasaan yang dimiliki. Peneliti berkesimpulan bahwa segala tindakan kecurangan muncul karena adanya ideologi bahwa segala tindakan yang mereka lakukan dengan segala keuntungan yang akan mereka dapatkan adalah hal yang telah menjadi kesepakatan bersama mahasiswa bahwa tindakan kecurangan dalam pencapaian akademik tidak perlu dipermasalahkan karena telah menjadi kebiasaan yang sulit dihilangkan karena segala keuntungan yang dimiliki.

\section{SIMPULAN}

Pengungkapan makna dari analisis semiotika Roland, dapat membawa kedalam pemahaman bahwa sifat feminin dan maskulin yang ada pada mahasiswa memegang peran penting dan andil tertentu pada aksi mahasiswa melakukan kecurangan. Kecurangan dilakukan karena ada tujuan yang dipandang penting, dalam hal ini guna memenuhi tujuan pencapaian prestasi akademik. Sifat femininitas yang berperan dalam melakukan aksi kecurangan yang dilakukan mahasiswa adalah sifat perfecsionist yang dimiliki, kepekaan melihat situasi dalam melancarkan aksi kecurangan, dan isyarat non verbal yang dilakukan pada saat ujian. Sedangkan sifat maskulin yang berperan yaitu keberanian dalam menanggung konsekuensi dari tindakan kecurangan yang dilaukan mahasiswa, didukung sifat solidaritas, dan kebersamaan melakukan tindakan tersebut. Secara umum machiavellian terjadi karena adanya kolektivitas kepentingan dari sebuah kelompok dengan tujuan yang sama. Segala temuan makna Roland Barthes dengan konsep gender menyampaikan makna bahwa, segala kecurangan yang timbul berdasarkan sifat feminin dan maskulin yang dimiliki mahasiswa dilakukan secara sadar dan terencana. Prosesnya dilakukan dengan menggunakan tanda dan bahasa simbol yang sangat sarat dengan makna dan menjadi mitos. Mulai dari pandangan mata, bunyi bisikan, kode tangan, gelengan dan anggukan kepala menjadi sangat bermakna. Segala hal dari praktik machialliean ini dipilih mahasiswa berdasarkan seberapa besar peluang praktik ini dilakukan dan segala keuntungan yang bisa mereka dapatkan.

Penelitian ini memiliki beberapa keterbatasan, yaitu sulitnya berperan sebagai mahasiswa yang ikut terlibat dalam ujian untuk melihat kondisi pada saat get in dikarenakan mengenal peneliti. Kesulitan juga terjadi saat mengungkapkan nilai feminitas dan maskulinitas karena kriteria hanya menggunakan jenis kelamin. Penelitian ini tidak melihat sanksi machiavellian berdasarkan aturan akademik yang berlaku. Untuk penelitian selanjutnya diharapkan dapat melihat berbagai perspektif secara keseluruhan yang mempengaruhi tindakan tidak etis yang dilakukan mahasiswa. Seperti melihat dari perspektif pendidik atau penelitian antara kedua belah pihak dan menggunakan metode yang berbeda seperti interaksi simbolik. Penelitian selanjutnya dalam konteks mengukur feminitas dan maskulinitas, perlu menggunakan alat ukur standar semisalnya bentuk tes psikolog atau hal lainnya yang saling berkaitan dalam pengukuran dan pengungkapan feminitas dan maskulinitas.

\section{REFERENCES}

Christie, R., dan Geis, F. (1970). Studies in Machiavellianism. New York: Academic Press.

Deddy, M., dan Veithzal, R. (2012). Kepemimpinan dan Perilaku Organisasi. Jakarta: PT. Raja Grafindo Persada.

Fakih, M. (2012). Analisis Gender dan Transformsi Sosial. Yogyakarta: Pustaka Pelajar.

Giddens, A. (2006). Sociology (edisi ke-5.). Jakarta: Gramedia.

Hartman, L. P., dan Desjardins, J. (2015). Etika Bisnis. Jakarta: Erlangga.

Ikatan Akuntan Indonesia. (2020). Kode Etik Akuntan Indonesia. Jakarta: Ikatan Akuntan Indonesia.

Jensen, M. C. dan Meckling, W. H. (1976). Theory of The Firm: Managerial Behaviour, Agency Costs and Ownership Structure. Journal of Financial Economics, 3(4), 305-360.

Kriyantono, R. (2009). Teknik Praktisi Riset Komunikasi. Jakarta: Kencana Prenada Media Group.

Mansfield, H. (2021). Niccolò Machiavelli. Didapat dari https:// www.britannica.com/biography/Ni ccolo-Machiavelli, 22 Juli 2021, pukul 20:00 WIB.

McQuail, D. (2011). Teori Komunikasi Massa (edisi ke-6). Jakarta: Salemba Empat.

Moleong, L. J. (2015). Metodologi Penelitian Kualitatif. Bandung: PT Remaja Rosdakarya.

Nash, L. (2002). The Nature of the Firm. Reviews in American History, 30(2), 266-272. 
Obalola, M., Aduloju, K., dan Olowokudejo, F. (2012). Organizational Commitment and Corporate Ethical Values: Exploring the Nexus between Employees' Psychological Contract and Firms' Ethical Behaviour in the Nigerian Insurance Industry. Journal of Management and Sustainability, 2(1), 43-56.

Purnamasari, S. V. (2006). Sifat Machiavellian dan Pertimbangan Etika: Anteseden Independensi dan Perilaku Etis Auditor. Prosiding. Simposium Nasional Akuntansi IX: Padang.

Rindayanti, dan Budiarto, D. S. (2017). Hubungan antara Love of Money, Machiavellian dengan Persepsi Etis: Analisis Berdasarkan Perspektif Gender. Akuntabilitas: Jurnal Ilmu Akuntansi, 10(2), 261-272.

Robbins, S. P. dan Judge, T. A. (2017). Perilaku Organisasi (edisi ke-13). Jakarta: Salemba Empat.

Robbins, S. (2015). Organizational Behavior (edisi ke-9). New Jersey: Precentice Hall International Inc.

Satori, D., dan Komariah, A. (2013). Metodologi Penelitian Kualitatif. Bandung: Alfabeta.

Shaleh, A. S. (2015). Filsafat Etika. Jakarta: Serambi Ilmu Semesta

Sobur, A. (2009). Semiotika Komunikasi. Bandung: PT Remaja Rosdakarya.

Sugiyono. (2012). Memahami Penelitian Kualitatif. Bandung: Alfabeta.

Sugiyono. (2018). Metode Penelitian Kuantitatif, Kualitatif dan R\&D. Bandung: Alfabeta.

Suprapto. (2009). Pengantar Teori Dan Manajemen Komunikasi. Yogyakarta: Medpress.

Suseno, F. M. (2020). Etika Dasar Masalah-Masalah Pokok Filsafat Moral (edisi ke-20.). Yogyakarta: Kanisius.

Tandirerung, C. J., Totanan, C., Mile, Y., Marsuddin, dan Paranoan, N. (2019). Perception of Farmers in Langa Leso Village Towards Subsidies. Journal of Advanced Research in Dynamical and Control Systems, 11(8), 2308-2314.

Totanan, C. (2021). Semiotika Utang Dalam Budaya Rambu Solo' Masyarakat Toraja: Akuntansinya Di Mana? Yogyakarta: Bildung.

Totanan, C., Sudirman, Umiati, U., Yamin, N. Y., Pakawaru, M. I. dan Mile, Y. (2020). Analysis Factors of Gender and Financial Accounting Learning Achievement as an Influential of Financial Literacy. Prosiding. 7 $^{\text {th }}$ International Conference on Community Development: Ho Chi Minh.
Wibowo, I. S. W. (2013). Semiotika Komunikasi Aplikasi Praktis Bagi Penelitian Skripsi Komunikasi. Jakarta: Mitra Wacana Media.

Wood, W., dan Eagly, A. H. (2002). A CrossCultural Analysis of the Behavior of Women and Men: Implications for the Origins of Sex Differences. Psychological Bulletin, 128(5), 699727.

Zubair, A. (2013). Potret Media Dalam Politik Indonesia. Jakarta: Fakultas Ilmu Komunikasi Universitas Mercu Buana. 